\title{
Assessment of Ozone Sensitivity in Three Wheat Cultivars Using Ethylenediurea
}

\author{
Adeeb Fatima ${ }^{1}$, Aditya Abha Singh ${ }^{1,2}$, Arideep Mukherjee ${ }^{1}$, Tsetan Dolker ${ }^{1}$, \\ Madhoolika Agrawal ${ }^{1}$ and Shashi Bhushan Agrawal ${ }^{1, *}$ \\ 1 Laboratory of Air Pollution and Global Climate Change, Department of Botany, Institute of Science, \\ Banaras Hindu University, Varanasi 221005, India; adeebfatima@yahoo.in (A.F.); \\ abha2512.singh@gmail.com (A.A.S.); arideep.mukherjee04@bhu.ac.in (A.M.); \\ tsetan.dolker3@bhu.ac.in (T.D.); madhoo@bhu.ac.in (M.A.) \\ 2 Department of Plant Molecular Biology, University of Delhi, South Campus, Delhi 110021, India \\ * Correspondence: sbhushan56@bhu.ac.in; Tel.: +91-9415309682
}

Received: 1 February 2019; Accepted: 26 March 2019; Published: 29 March 2019

\begin{abstract}
Three wheat (Triticum aestivum L.) cultivars [HD 2987 (ozone $\left(\mathrm{O}_{3}\right)$ sensitive), PBW 502 (intermediately sensitive) and Kharchiya $65\left(\mathrm{O}_{3}\right.$ tolerant)] with known sensitivity to $\mathrm{O}_{3}$ were re-evaluated using ethylenediurea (EDU; $400 \mathrm{ppm}$ ) to ascertain the use of EDU in determining $\mathrm{O}_{3}$ sensitivity under highly $\mathrm{O}_{3}$-polluted tropical environments. EDU treatment helped in improving the growth, biomass, photosynthetic pigments and the antioxidative defense system of all the wheat cultivars. Under EDU treatment, PBW 502 retained more biomass, while HD 2987 showed better performance and ultimately the greatest increment in yield. Cultivar Kharchiya 65 also showed a positive response to EDU as manifested with an increase in pigment contents, total biomass and enzymatic antioxidants; however, this increment was comparatively lower compared to the other two cultivars. The results indicated that EDU did not have many physiological effects on cultivars but helped in counteracting $\mathrm{O}_{3}$ primarily by scavenging reactive oxygen species and enhancing the antioxidative defense system where superoxide dismutase emerged as the major responsive biochemical parameter against ambient $\mathrm{O}_{3}$. The observed results clearly indicated that differential $\mathrm{O}_{3}$ sensitivity in three wheat cultivars established by the previous study is in accordance with the present study using EDU as a sensitivity tool, which is an easy and efficient technology in comparison to chamber and Free-Air Carbon dioxide Enrichment (FACE) experiments although its mechanistic understanding needs to be further validated.
\end{abstract}

Keywords: antioxidants; biomass; ethylenediurea; ozone sensitivity; yield

\section{Introduction}

Tropospheric ozone $\left(\mathrm{O}_{3}\right)$ is a spatially and temporally dynamic air pollutant as well as a powerful greenhouse gas [1]. This increasing air pollutant of the lower atmosphere has negatively influenced food security, thereby causing tremendous loss to the growth and productivity of various crops. FAO (2009) predicted that, by 2050, the global population will reach 9.1 billion, with a consequent demand of at least a $70 \%$ increase in agricultural production and $\mathrm{O}_{3}$ will particularly cause much hindrance in achieving this target [2]. The concentration of $\mathrm{O}_{3}$ has increased more than two-fold globally in recent times compared to the pre-industrial era [3]. A distinct correlation also exists between the peak $\mathrm{O}_{3}$ concentration and major crop growing season, resulting in high yield losses [4]. Global yield losses due to $\mathrm{O}_{3}$ in major crops such as wheat, rice, maize and soybean were $4-15 \%, 3-4 \%, 2-5 \%$ and $5-15 \%$, respectively [4,5]; however, for the year 2000, it was found that $40 \%$ of these losses were from India and China [4]. As per the projection of a new study, a $40 \%$ increase in $\mathrm{O}_{3}$ concentration is expected in 
the South Asian region by the year 2050 [6]. Based on mean $\mathrm{O}_{3} 7 \mathrm{~h}(\mathrm{M7})$ and accumulated $\mathrm{O}_{3}$ over a threshold of $40 \mathrm{ppb}$ (AOT 40) metrics, Lal et al. (2017) estimated an annual total yield loss of 4-14.2 million tonnes (4.2-15\%) of wheat production in India during 2011-2014 [7]. However, in the absence of stricter air pollution regulation, India will have to face more crop yield losses in the future due to $\mathrm{O}_{3}$ pollution.

Different techniques and chemical tools have been used to assess the level of economic losses from $\mathrm{O}_{3}$ exposure, of which ethylenediurea (EDU, N-[2-(2-oxo-1-imidazolidinyl) ethyl]-N'-phenylurea) has widely emerged as a clear indicator in the assessment of EDU-induced protection in plants against $\mathrm{O}_{3}$. It was first used by Carnahan et al. (1978), and showed a positive effect on plant productivity against ambient $\mathrm{O}_{3}$ [8]. EDU-dependent $\mathrm{O}_{3}$ tolerance occurs by modifying plant processes at the cellular level, ultimately protecting plant yield from $\mathrm{O}_{3}$ damage [9]. Feng et al. (2018) found EDU to be effective in increasing yield which decreased by $20.3 \%$ in non-EDU-treated wheat cultivars, and it has also been used to screen for $\mathrm{O}_{3}$-sensitive/tolerant cultivars [10]. EDU treatment (500 ppm) to Sesame increased stomatal conductance $\left(g_{s}\right)$ and the net photosynthesis rate $\left(P_{s}\right)$ by 52 and $61 \%$, respectively, compared to plants without EDU treatment [11], while Singh et al. (2010) noticed higher ascorbic acid content in mung bean plants with EDU application, and peroxidase (POX) and superoxide dismutase (SOD) activities were significantly declined [12]. A recent study by Pandey et al. (2019) demonstrated that EDU can be widely used in large scale screening for $\mathrm{O}_{3}$ tolerance in different wheat cultivars under different environments [13]. EDU thus effectively protects and also helps in estimating the extent of $\mathrm{O}_{3}$ damage to crop plants. To date, $\mathrm{O}_{3}$ sensitivity is identified in different cultivars based on chamber and Free-Air Carbon dioxide Enrichment (FACE) experiments which are costly and require sufficient instrumentation, while sensitivity assessment using EDU under ambient conditions is rather effective and can be directly used for screening in developing countries.

Wheat is one of the most important staple crops in the world after maize [14] and its sensitivity to $\mathrm{O}_{3}$ is known to be cultivar specific $[9,15]$. Thus, this present study was conducted on three tropical wheat cultivars to assess the severity of $\mathrm{O}_{3}$ damage using EDU as a chemical tool. We hypothesized that EDU will help in validating the cultivar-specific $\mathrm{O}_{3}$ sensitivity of wheat and also change either the physiological parameters or the antioxidative defense system, contributing to variations in yield under ambient $\mathrm{O}_{3}$ conditions. Therefore, we used EDU as a tool with the following objectives: (1) to confirm the relative sensitivity of selected wheat cultivars already categorized to be sensitive, intermediately sensitive and tolerant against $\mathrm{O}_{3},(2)$ to assess whether these cultivars differ in their physiological or biochemical responses to $\mathrm{O}_{3}$, and (3) to find the most influential parameters of $\mathrm{O}_{3}$ sensitivity in wheat cultivars. This knowledge will help in validating the use of EDU in the screening of cultivars for $\mathrm{O}_{3}$ sensitivity for cultivation in a particular area and identification of some important parameters present in tolerant cultivar for breeding purposes.

\section{Results}

The mean monthly ambient $\mathrm{O}_{3}$ concentration of $56.7 \mathrm{ppb}$ (maximum) was observed in March and a minimum of $46.8 \mathrm{ppb}$ was observed in February, while the seasonal mean $\mathrm{O}_{3}$ concentration was $49.6 \mathrm{ppb}$. Likewise, the maximum AOT 40 value of $2939.4 \mathrm{ppb}$ h was observed in the month of March and the cumulative AOT 40 value observed for the ambient $\mathrm{O}_{3}$ environment was $9168.21 \mathrm{ppb}$ h during the experimental period.

Growth parameters (plant height, total biomass and number of tillers) were positively influenced by EDU treatment in all the tested cultivars (Tables 1 and 2). At 60 days after germination (DAG), the plant height increased maximally by $14.4 \%$ in HD 2987, while it increased least in Kharchiya 65 , by $6.2 \%$.The number of tillers was maximally increased in PBW 502 by $57.1 \%$ and it increased least in Kharchiya 65 , by $31.8 \%$, while the total biomass increased by $34.3 \%$ in PBW 502 followed by $22.3 \%$ in HD 2987 and least in Kharchiya 65 by 12.2\%.A split-plot ANOVA also found a significant effect of EDU treatment and cultivars for all the growth parameters (Table 1). Among the growth parameters, the total biomass showed the maximum influence of EDU treatment while the number of senesced 
leaves was least affected. The interactive effect of EDU treatment and cultivars were only significant $(p<0.05)$ for biomass and the number of senesced leaves.

Table 1. Results of the split-plot ANOVA with their respective df (degrees of freedom), $F$ ( $F$-value) and $p$ (significance level) values for each of the studied parameters $(\mathrm{n}=9)$. EDU treatment and cultivar are individual factors while EDU $\times$ Cultivar is the interactive factor. Here, $\mathrm{P}_{\mathrm{s}}$ : photosynthesis rate, $\mathrm{g}_{\mathrm{s}}$ : stomatal conductance and Fv/Fm: photosynthetic efficiency, APX: ascorbate peroxidase, POX: peroxidase, CAT: catalase and SOD: superoxide dismutase.

\begin{tabular}{cccccccccc}
\hline \multirow{2}{*}{ Parameters } & \multicolumn{3}{c}{ EDU Treatment } & \multicolumn{3}{c}{ Cultivar } & \multicolumn{3}{c}{ EDU $\times$ Cultivar } \\
\cline { 2 - 10 } & $\mathbf{d f}$ & $\boldsymbol{F}$ & $\boldsymbol{p}$ & $\mathbf{d f}$ & $\boldsymbol{F}$ & $\boldsymbol{p}$ & $\mathbf{d f}$ & $\boldsymbol{F}$ & $\boldsymbol{p}$ \\
\hline Total biomass & 1 & 154 & $<0.001$ & 2 & 186 & $<0.001$ & 2 & 15.34 & 0.014 \\
Plant height & 1 & 17.39 & 0.013 & 2 & 54.55 & $<0.001$ & 2 & 2.76 & 0.122 \\
No. of tillers per plant & 1 & 60.5 & 0.001 & 2 & 19.92 & 0.001 & 2 & 0.071 & 0.932 \\
No. of senesced leaves & 1 & 5.56 & 0.078 & 2 & 19.85 & 0.005 & 2 & 10.42 & 0.018 \\
No. of leaves & 1 & 10.91 & 0.030 & 2 & 2.935 & 0.111 & 2 & 0.131 & 0.879 \\
Total chlorophyll & 1 & 207 & $<0.001$ & 2 & 219 & $<0.001$ & 2 & 314 & $<0.001$ \\
Carotenoids & 1 & 119 & $<0.001$ & 2 & 256 & $<0.001$ & 2 & 335 & $<0.001$ \\
Ps & 1 & 59.1 & 0.002 & 2 & 4.03 & 0.073 & 2 & 0.76 & 0.482 \\
gs & 1 & 9.04 & 0.040 & 2 & 17.99 & 0.005 & 2 & 0.385 & 0.690 \\
Fv /Fm & 1 & 40.79 & 0.003 & 2 & 10.34 & 0.013 & 2 & 3.032 & 0.105 \\
SOD & 1 & 374.1 & $<0.001$ & 2 & 300.2 & $<0.001$ & 2 & 138.6 & $<0.001$ \\
POX & 1 & 121.3 & $<0.001$ & 2 & 227.2 & $<0.001$ & 2 & 197.5 & $<0.001$ \\
CAT & 1 & 106.9 & $<0.001$ & 2 & 107.1 & $<0.001$ & 2 & 66.9 & $<0.001$ \\
APX & 1 & 0.205 & 0.674 & 2 & 145.1 & $<0.001$ & 2 & 33.95 & 0.001 \\
Superoxide radical & 1 & 87.11 & $<0.001$ & 2 & 111.4 & $<0.001$ & 2 & 91.95 & $<0.001$ \\
Production rate & 1 & 134 & $<0.001$ & 2 & 103.9 & $<0.001$ & 2 & 2.064 & 0.219 \\
Yield & 1 & & & & & & & &
\end{tabular}

Table 2. Effect of EDU treatment on the growth, total biomass and physiology of wheat cultivars under ambient $\mathrm{O}_{3}$ conditions. Here, $\mathrm{P}_{\mathrm{s}}$ : photosynthesis rate, $\mathrm{g}_{\mathrm{s}}$ : stomatal conductance, and Fv /Fm: photosynthetic efficiency. Values are mean $\pm S E ; n=9$. Symbols above the bars represent significant variability between EDU- and non-EDU-treated plants. The one, two and three asterisks indicate the significance levels at ${ }^{*} p \leq 0.05,{ }^{* *} p \leq 0.01$, and ${ }^{* * *} p \leq 0.001$, and ns is non-significant. Significant variations between cultivars under EDU and non-EDU treatment are respectively represented by different capital and small letters $(p<0.05)$.

\begin{tabular}{|c|c|c|c|c|}
\hline Cultivars & Parameters & Non-EDU Treated & EDU-Treated & Significance \\
\hline \multirow{6}{*}{ HD 2987} & Plant height $(\mathrm{cm})$ & $84.76 \pm 0.38^{b}$ & $97.00 \pm 0.57^{\mathrm{B}}$ & $* * *$ \\
\hline & No. of tillers plant ${ }^{-1}$ & $4.33 \pm 0.33^{b}$ & $6.66 \pm 0.33^{\mathrm{B}}$ & $* *$ \\
\hline & Total biomass (g) & $5.96 \pm 0.08^{b c}$ & $7.30 \pm 0.15^{\mathrm{BC}}$ & $* *$ \\
\hline & $\mathrm{P}_{\mathrm{S}}\left(\mu \mathrm{mol} \mathrm{CO} 2 \mathrm{~m}^{-2} \mathrm{~s}^{-1}\right)$ & $16.24 \pm 0.83^{b}$ & $21.84 \pm 0.15^{\mathrm{A}}$ & $* *$ \\
\hline & $\mathrm{g}_{\mathrm{s}}\left(\mathrm{mol} \mathrm{m} \mathrm{m}^{-2} \mathrm{~s}^{-1}\right)$ & $0.69 \pm 0.04^{\mathrm{a}}$ & $0.81 \pm 0.01^{\mathrm{A}}$ & * \\
\hline & $\mathrm{Fv} / \mathrm{Fm}$ & $0.71 \pm 0.01^{b}$ & $0.79 \pm 0.01^{\mathrm{A}}$ & * \\
\hline \multirow{6}{*}{ PBW 502} & Plant height $(\mathrm{cm})$ & $85.76 \pm 0.58^{b}$ & $95.20 \pm 0.96^{\mathrm{B}}$ & ** \\
\hline & No. of tillers plant ${ }^{-1}$ & $4.66 \pm 0.33^{b}$ & $7.33 \pm 0.67^{\mathrm{B}}$ & * \\
\hline & Total biomass (g) & $7.66 \pm 0.06^{\mathrm{ac}}$ & $10.30 \pm 0.05 \mathrm{AC}$ & $* * *$ \\
\hline & $\mathrm{P}_{\mathrm{S}}\left(\mu \mathrm{mol} \mathrm{CO} 2 \mathrm{~m}^{-2} \mathrm{~s}^{-1}\right)$ & $16.48 \pm 0.46^{b}$ & $19.79 \pm 1.75^{\mathrm{A}}$ & ns \\
\hline & $\mathrm{g}_{\mathrm{s}}\left(\mathrm{mol} \mathrm{m} \mathrm{m}^{-2} \mathrm{~s}^{-1}\right)$ & $0.50 \pm 0.04^{\mathrm{a}}$ & $0.60 \pm 0.04^{\mathrm{B}}$ & $*$ \\
\hline & $\mathrm{Fv} / \mathrm{Fm}$ & $0.77 \pm 0.01^{\mathrm{ab}}$ & $0.82 \pm 0.01^{\mathrm{A}}$ & * \\
\hline
\end{tabular}


Table 2. Cont

\begin{tabular}{|c|c|c|c|c|}
\hline Cultivars & Parameters & Non-EDU Treated & EDU-Treated & Significance \\
\hline \multirow{6}{*}{ Kharchiya 65} & Plant height $(\mathrm{cm})$ & $125.23 \pm 0.66^{\mathrm{a}}$ & $132.96 \pm 0.79 \mathrm{~A}$ & ** \\
\hline & No. of tillers plant ${ }^{-1}$ & $7.33 \pm 0.67^{\mathrm{a}}$ & $9.67 \pm 0.33^{\mathrm{A}}$ & * \\
\hline & Total biomass (g) & $10.33 \pm 0.06^{\mathrm{ab}}$ & $11.60 \pm 0.20 \mathrm{AB}$ & $* *$ \\
\hline & $\mathrm{P}_{\mathrm{s}}\left(\mu \mathrm{mol} \mathrm{CO} 2 \mathrm{~m}^{-2} \mathrm{~s}^{-1}\right)$ & $21.07 \pm 1.36^{\mathrm{a}}$ & $23.12 \pm 1.83^{\mathrm{A}}$ & ns \\
\hline & $\mathrm{g}_{\mathrm{s}}\left(\mathrm{mol} \mathrm{m} \mathrm{m}^{-2} \mathrm{~s}^{-1}\right)$ & $0.62 \pm 0.02^{\mathrm{a}}$ & $0.78 \pm 0.01^{\mathrm{A}}$ & $* *$ \\
\hline & $\mathrm{Fv} / \mathrm{Fm}$ & $0.80 \pm 0.02^{\mathrm{a}}$ & $0.81 \pm 0.00^{\mathrm{A}}$ & ns \\
\hline
\end{tabular}

Significant changes $(p<0.001)$ in the total chlorophyll and carotenoids content were prominent in all the EDU-treated cultivars compared to the plants which remained untreated with EDU (Figure 1). Total chlorophyll content maximally increased upon EDU treatment in HD 2987 (77.7\%), by 11.1\% in PBW 502 and by 36.3\% in Kharchiya 65 at 60 days after germination (DAG) (Figure 1). Carotenoids also showed a varied response in all the three test cultivars after EDU treatment. At 60 DAG, the increment was highest in Kharchiya 65 (35.8\%), while the increment was lowest in HD 2987 (12.5\%) and a reduction of 8.3\% was exhibited by PBW 502 (Figure 1). The number of leaves plant ${ }^{-1}$ were significantly more in EDU-treated plants compared to non-EDU-treated plants $(31,35$ and $18 \%$ in HD 2987, PBW 502 and Kharchiya 65, respectively), while the number for senesced leaves plant ${ }^{-1}$ decreased at 60 DAG displaying that EDU enhanced the leaf greenness. EDU-treated cultivars showed an obvious decrease in the number of senesced leaves by 75\% in HD 2987, 19\% in PBW 502 and 47.3\% in Kharchiya 65 (Figure 1). Results of the split-plot ANOVA also showed a significant effect $(p<0.001)$ of EDU treatment on the number of leaves; however, the effect was non-significant $(p=0.078)$ for the number for senesced leaves plant ${ }^{-1}$ (Table 1$)$.

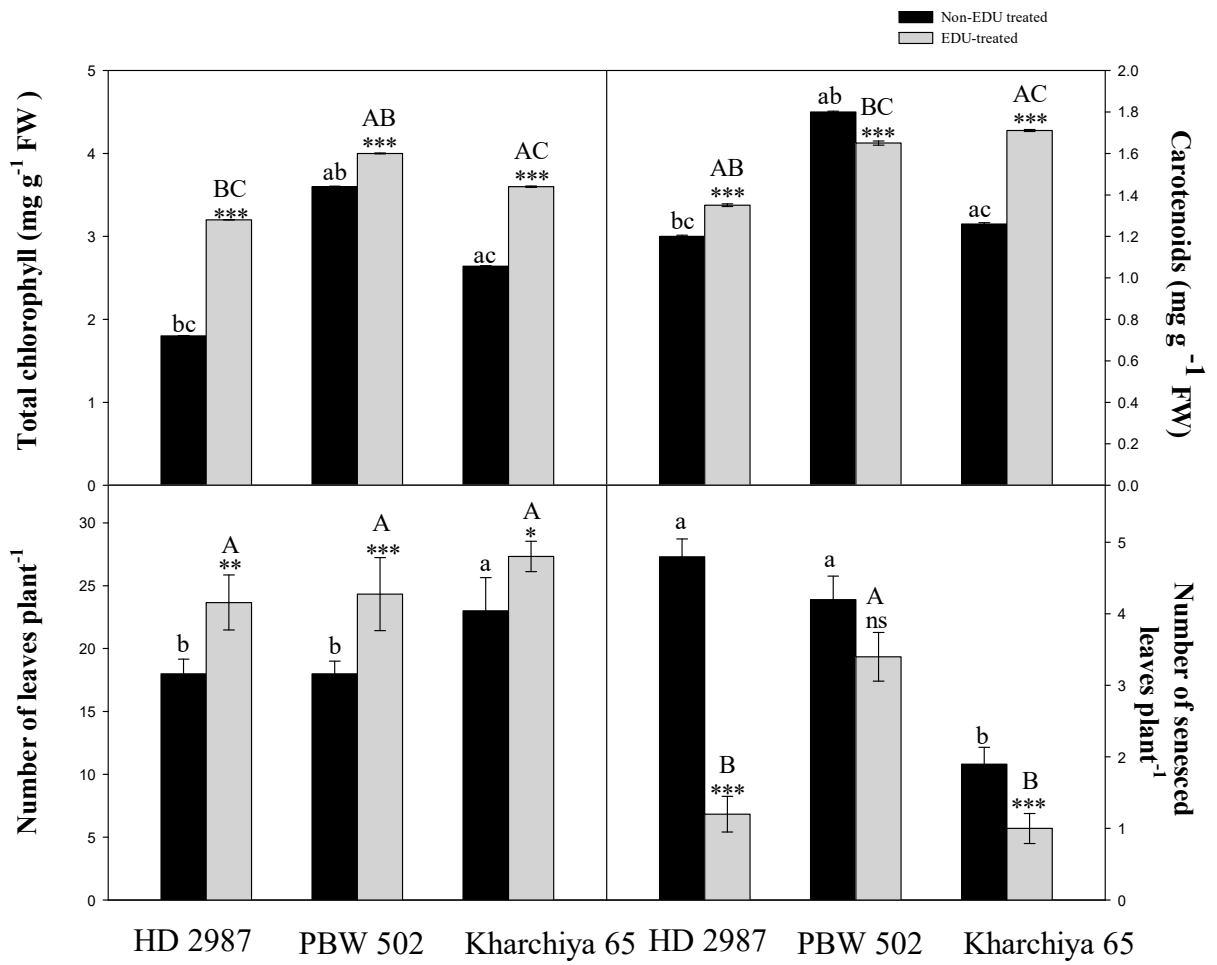

Figure 1. Effect of EDU treatment on total chlorophyll, carotenoids, number of leaves per plant and number of senesced leaves per plant in three cultivars of wheat. Values are mean $\pm \mathrm{SE} ; \mathrm{n}=9$. Symbols above the bars represent significant variability between EDU- and non-EDU-treated plants. The one, two and three asterisks indicate the significance levels at ${ }^{*} p \leq 0.05,{ }^{* *} p \leq 0.01$, and ${ }^{* * *} p \leq 0.001$, and ns is non-significant. Significant variations between cultivars under EDU and non-EDU treatment are respectively represented by different capital and small letters $(p<0.05)$.

Under EDU treatment, $\mathrm{P}_{\mathrm{S}}$ increased maximally by 34.4\% in HD $2987(p<0.05)$ and least in Kharchiya 65 by $9.7 \%$, while $g_{s}$ increased maximally by $26.5 \%$ in Kharchiya 65 and minimally in HD 2987 by 17.3\% (Table 2). Chlorophyll fluorescence, i.e., Fv / Fm, was maximally increased in HD 2987 by $12 \%$ and minimally by $1.4 \%$ in Kharchiya 65 , although the response was non-significant under EDU treatment. Among the physiological parameters, the maximum significant $(p<0.05)$ effect of 
EDU treatment was observed in Ps while $g_{s}$ was least affected; however, the effect of the cultivar was non-significant $(p=0.078)$ in the case of Ps (Table 1). For all the physiological parameters, the effect of the interaction between EDU treatment and cultivars were non-significant $(p>0.05)$.

In the EDU-treated cultivars, the enzymatic antioxidants displayed a variable trend. The results of split-plot ANOVA also revealed a significant effect $(p<0.001)$ of the EDU treatment, cultivars and their interaction on all the selected enzymatic antioxidants except APX (Table 1). SOD was found to be the most affected parameter by EDU treatment (Table 1). The maximum increase in SOD activity was in HD 2987 (11.9\%), while the least induction was in Kharchiya 65 being 5\% in EDU-treated plants (Figure 2). The superoxide radical production rate (SOR) was significantly and maximally reduced by $21 \%$ in HD 2987, followed by 11.6 and 6\% in cultivars PBW 502 and Kharchiya 65, respectively. Catalase (CAT) activity also showed a trend of increase after EDU application, being highest in HD 2987 (27\%) and lowest in Kharchiya 65 (6.5\%). POX activity reduced maximally in HD 2987, by 14.1\%, while it decreased by $7.7 \%$ and $11.1 \%$ in PBW 502 and Kharchiya 65, respectively. APX activity declined after EDU supplementation in HD 2987 by 13.5\%. However, an induction in the APX activity was in Kharchiya 65 (8.4\%) and there was a non-significant increase of $0.4 \%$ in PBW 502 upon EDU treatment compared to the non-EDU-treated ones (Figure 2).

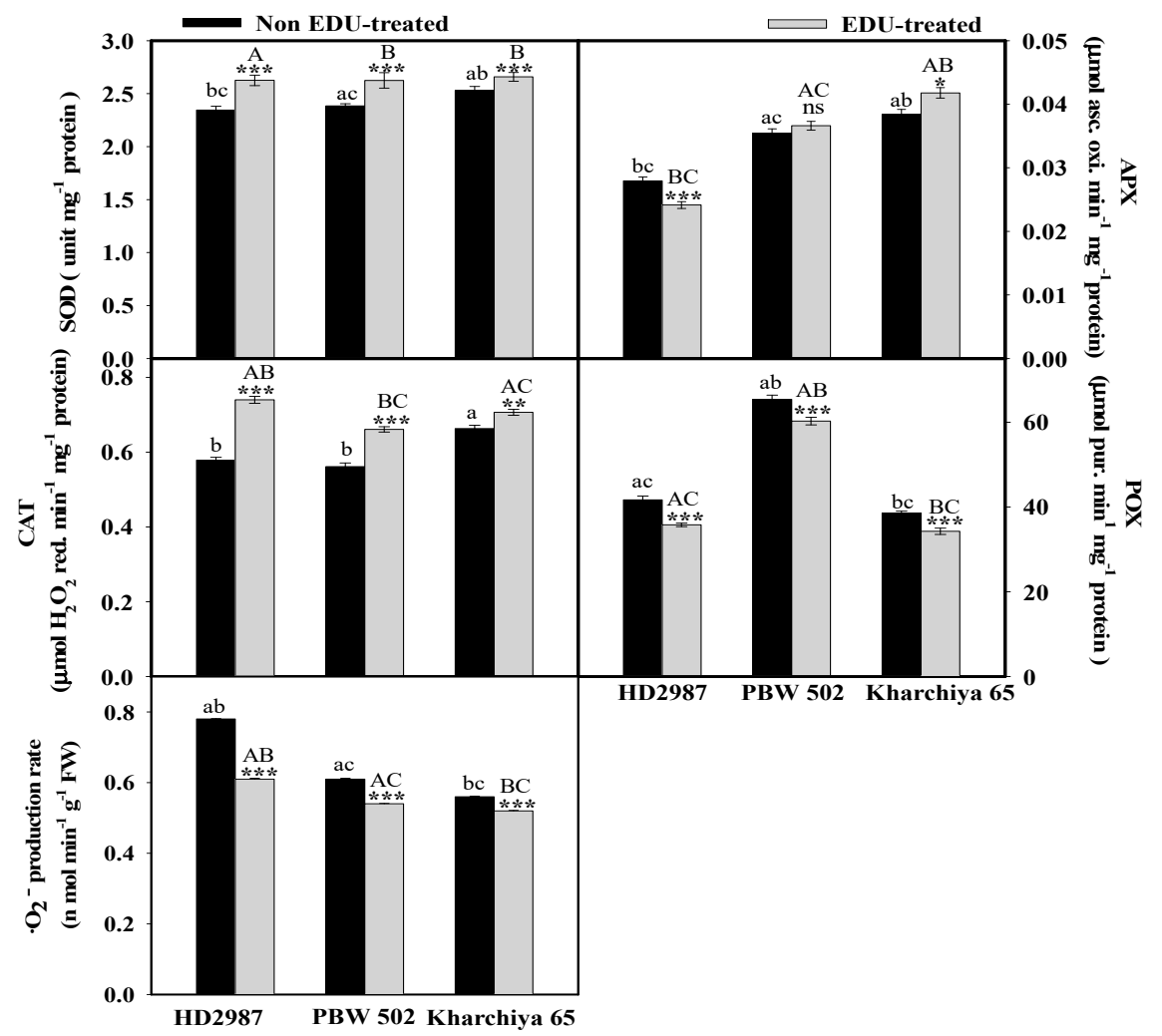

Figure 2. Effect of EDU on antioxidative enzymes such as superoxide dismutase (SOD), ascorbate peroxidase (APX), catalase (CAT), peroxidase (POX) and the superoxide radical production rate (SOR) in wheat cultivars. Values are mean $\pm \mathrm{SE} ; \mathrm{n}=9$. Symbols above the bars represent significant variability between EDU- and non-EDU-treated plants. The one, two and three asterisks indicate the significance levels at ${ }^{*} p \leq 0.05,{ }^{* *} p \leq 0.01$, and ${ }^{* * *} p \leq 0.001$, and ns is non-significant. Significant variations between cultivars under EDU and non-EDU treatment are respectively represented by different capital and small letters $(p<0.05)$.

EDU application resulted in an improvement in the yield (weight of grains plant ${ }^{-1}$ ) of HD 2987 (32.9\%), PBW 502 (13.3\%) and Kharchiya 65 (8.8\%). Therefore, EDU application confirmed its suitability for identifying the cultivar susceptibility against $\mathrm{O}_{3}$ stress considering the economic yield (Figure 3 ). 


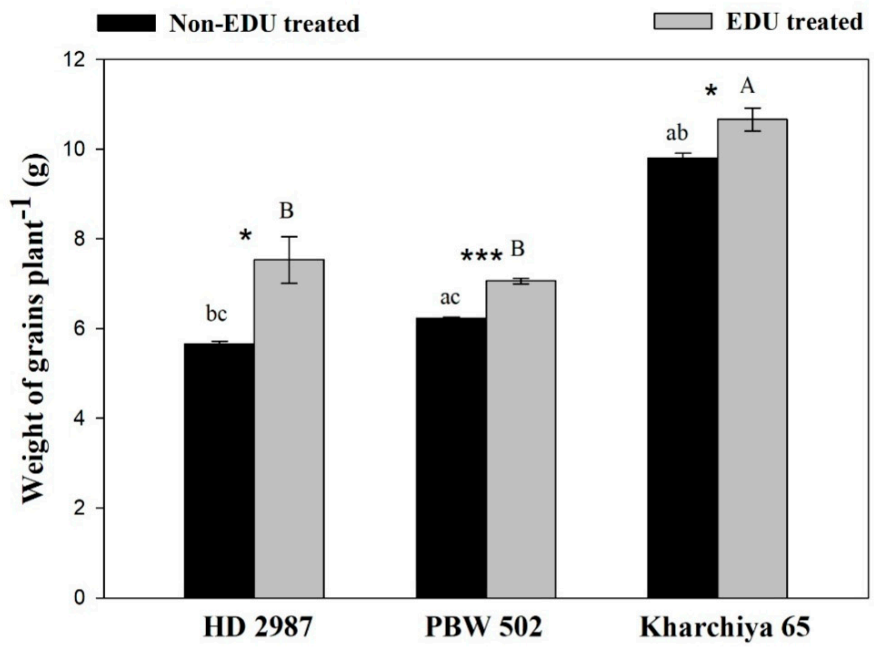

Figure 3. Yield (weight of grains per plant) of three wheat cultivars as affected under EDU treatment. Values are mean $\pm \mathrm{SE} ; \mathrm{n}=9$. Symbols above the bars represent significant variability between EDU- and non-EDU-treated plants. The one, two and three asterisks indicate the significance levels at $* \leq 0.05$, ${ }^{* *} p \leq 0.01$, and ${ }^{* * *} p \leq 0.001$, and $\mathrm{ns}$ is non-significant. Significant variations between cultivars under EDU and non-EDU treatment are respectively represented by different capital and small letters $(p<0.05)$.

Based on the PCA results (Figure 4), the total variance explained by three components was $89.7 \%$, while it was $48.2 \%, 26.9 \%$ and $14.5 \%$ by components 1,2 and 3, respectively. Parameters such as SOD, CAT, plant height, number of tillers, total biomass and $\mathrm{P}_{\mathrm{s}}$ were closely related irrespective of other parameters showing a high association between them. In component 1, SOD showed the highest loading of 0.937 followed by a number of tillers (0.930).

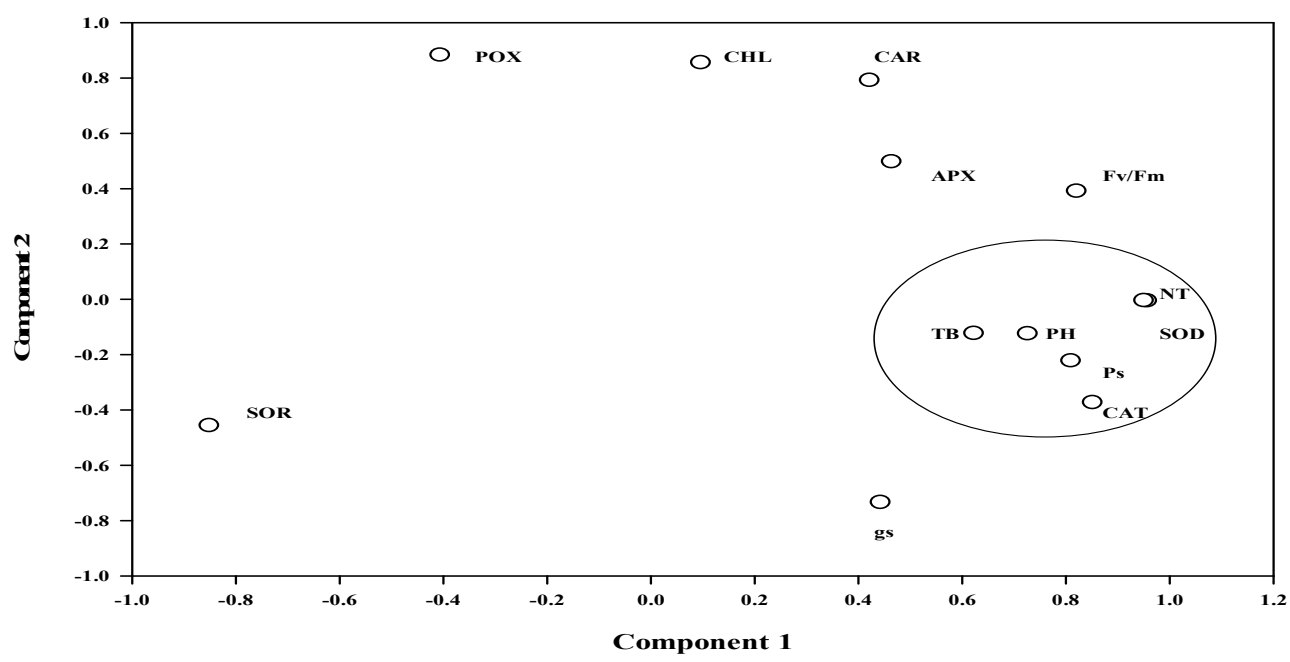

Figure 4. Principal component analysis results showing an association of the parameters on component axes. Here, PH, NT, TB, Ps, gs, Fv /Fm, CHL, CAR, SOD, POX, CAT and APX are the plant height, number of tillers, total biomass, photosynthetic rate, stomatal conductance, photosynthetic efficiency, chlorophyll, carotenoids, superoxide dismutase, peroxidase, catalase and ascorbate peroxidase, respectively.

\section{Discussion}

EDU has been verified as a simple and effective chemical tool to evaluate and assess $\mathrm{O}_{3}$ phytotoxicity under ambient conditions [16,17]. During the growing season of wheat, the high mean ambient $\mathrm{O}_{3}$ and AOT 40 values in our experiment were well correlated to the concentrations 
reported by other studies from India [9,18], having a significant effect on the growth and productivity of various crops.

In our experiment, EDU-treated wheat cultivars showed significant enhancements in plant height and number of tillers, indicating $\mathrm{O}_{3}$ stress-induced suppression in growth characteristics. Moreover, plant growth characteristics were highly improved under EDU treatment in both the sensitive and intermediately sensitive cultivars. Tiwari et al. (2005) also found improved morphological characteristics (plant height and number of tillers) in EDU-treated wheat cultivars [19] while under $50 \mathrm{ppb} \mathrm{O}_{3}$; EDU application of $400 \mathrm{ppm}$ caused a significant rise in height of mung bean plants [20]. Among the morphological traits, only the total biomass and number of senesced leaves showed significant variability due to the interactive effect of both treatment and cultivar. Such results indicate that both of these parameters depend upon EDU treatment with different magnitudes, suggesting that the intrinsic defense mechanism and resource utilization strategies are differentially altered by EDU in different cultivars in the presence of EDU.

We also found increments in the photosynthetic pigments under EDU treatment compared to non-EDU-treated plants. Besides, the sensitive cultivar showed significantly higher chlorophyll content in comparison to two other cultivars under EDU treatment. As the sensitive cultivars are more shielded to the negative influence of $\mathrm{O}_{3}$ compared to other cultivars, $\mathrm{O}_{3}$ stress might have induced more pigment synthesis instead of an induction in defense response. The results observed in mustard cultivars, Kranti and Peelasona, also showed increased chlorophyll content upon EDU treatment owing to the reduced destruction of chlorophyll [21]. The positive effect of EDU on photosynthetic pigments is well documented [12,22]. Pre-treatment with EDU has been conferred to protect against the $\mathrm{O}_{3}$-induced loss of chlorophyll [23]. Another pigment (i.e., carotenoids) imparts protection against photo-oxidative damage by the effective quenching of free radicals and, thus, helps in maintaining higher contents of chlorophyll. Therefore, increased carotenoids content upon EDU treatment would also have helped the plants in maintaining higher chlorophyll content for a long time. Similarly, EDU-treated soybean plants showed increased total chlorophyll and carotenoids content by $13.6 \%$ and $12.1 \%$, respectively, than non-EDU-treated plants [22]. In the present experiment, plants of tolerant cultivar Kharchiya 65 showed an increase in carotenoids compared to the other two cultivars. Another study also reported greater carotenoids content in Pinto bean, depicting a direct effect of EDU ( $\left.500 \mathrm{mg} \mathrm{L}^{-1}\right)$ treatment on them [24]. All three wheat cultivars displayed a delay in senescence under EDU treatment and it was keenly observed that one of the effective means by which EDU conferred protection to cultivar HD 2987 was by maintaining higher chlorophyll content under ambient $\mathrm{O}_{3}$ conditions. EDU has been known to have a cytokinin-like mode of action and, thus, helped to retain chlorophyll by minimizing oxidative stress and delaying the process of senescence [25]. Additionally, an increase in carotenoids content also supports the anti-senescent property of EDU as it also helps in preventing chlorophyll damage from photo-oxidation during stress conditions.

Ozone causes a reduction in $\mathrm{C}$ assimilation due to decreased Rubisco activity or impaired stomatal function, leading to a decline in $C$ availability in leaves [26]. Under EDU treatment, the sensitive cultivar showed a significant rise in $P_{s}$, reflecting that EDU effectively maintains a higher rate of $P_{S}$. However, in the case of other two cultivars, there were no significant effects on $P_{S}$ EDU application. Higher $P_{\mathrm{s}}$ in the sensitive cultivar is also directly correlated with higher pigment and carotenoids content under EDU treatment compared to other cultivars. Higher Ps and total chlorophyll content might be the reason for the increased total biomass of the sensitive cultivar in our study which was also confirmed in previous studies [27]. Tiwari et al. (2005) found a significant positive influence on total biomass as well as on shoot, leaf and root weights of wheat cultivars [19] whereas another study showed a $24 \%$ increment in the total biomass of mung bean plants after EDU supplementation [20]. Similar findings were also reported by Pandey et al. (2014) in cultivars of Brassica campestris [21] and by Singh et al. (2018) in maize cultivars [28]. The present study showed that EDU supplementation helped the wheat plants to maintain more biomass under ambient $\mathrm{O}_{3}$ conditions. It is a matter of great interest as to how, without a significant increase in photosynthesis, EDU-treated plants grew better and 
accumulated more biomass. This could be well satisfied with the explanation that reduced resource utilization for the antioxidative defense system under EDU treatment supported more growth and the biomass characteristics of wheat plants. Most results from earlier works suggest a non-significant effect of EDU on photosynthesis [23,29]. A meta-analytical study revealed that EDU-mediated protection against $\mathrm{O}_{3}$ was biochemical rather than biophysical [23]. Due to the complex nature of $\mathrm{O}_{3}$ action on stomata, there is no specific EDU effect on stomatal conductance [30]. Although in the present study, $\mathrm{g}_{\mathrm{s}}$ was partially influenced by EDU treatment only in the intermediately sensitive cultivar while the effect was non-significant for the sensitive as well as the tolerant cultivars due to EDU application, which again highlights the fact that EDU might influence plants by its protective mechanism and not by enhancing or altering different physiological processes or the entry of $\mathrm{O}_{3}$ through stomata. Rai et al. (2015) recorded significant increases in the Fm and Fv values in EDU-treated plants compared to non-EDU-treated plants, whereas the Fo and Fv/Fm ratio did not vary significantly between the two treatments [22]. We also observed a similar finding where Fv/Fm did not show a significant response across all test cultivars under EDU treatment, although the overall effect was significant and that might be due to different reasons such as the antioxidative status of different cultivars, photosynthetic repair mechanisms and accessory pigment contents. The biophysical and physiological parameters tested in the present study were not influenced by EDU treatment in all of the cultivars, suggesting that a single physiological process is not the direct target of EDU in enhancing stress tolerance against $\mathrm{O}_{3}$. Instead, the EDU response appears to involve a complex interaction of processes that modulate plant physiological efficiency.

It has been hypothesized that EDU results in less $C$ investment in the antioxidative defense mechanism for the repair of $\mathrm{O}_{3}$-induced damage and a major proportion of $\mathrm{C}$ can be utilized for growth and development [31]. The responses of antioxidant enzymes were in accordance with the results observed in the literature for other species treated by EDU [17,28,32]. Rai et al. (2015) found significant increase of $11.1 \%$ and $18.5 \%$ in activities of SOD and APX in EDU-treated than non-EDU-treated soybean plants [22]. In our experiment, both SOD and CAT were highly responsive in the sensitive cultivar. Likewise, SOD and CAT activities were also induced in the sensitive clover cultivar Wardan under EDU treatment [33]. Lower accumulation of $\mathrm{O}_{2}{ }^{-}$radical in all the cultivars is directly related to the differential activities of different antioxidative enzymes upon EDU treatment. It was demonstrated that EDU halted reactive oxygen species (ROS) production in Phaseolus vulgaris L. plants within $24 \mathrm{~h}$ of $\mathrm{O}_{3}$ treatment, resulting in decreased $\mathrm{H}_{2} \mathrm{O}_{2}$ production [34]. Possible modes of EDU action are the direct scavenging of $\mathrm{ROS}$ generated by $\mathrm{O}_{3}$ [35] or up-regulation of the antioxidative defense system in plants $[23,31]$. Supporting this, the present study showed a higher stimulation of antioxidative enzyme activityupon EDU treatment, particularly, in the activity of SOD, which is normally associated with $\mathrm{O}_{3}$ tolerance. While both SOD and CAT activities were found to be the most affected parameters across 18 rice cultivars when assessed with EDU against a high $\mathrm{O}_{3}$ concentration [17]. Besides, the other relevant enzyme POX decreased in all the assessed wheat cultivars under EDU treatment as also observed by Tiwari and Agrawal (2010) [27]. They also discarded EDU as a potent antioxidant but emphasized its role in maintaining higher levels of antioxidants under $\mathrm{O}_{3}$ stress with better physiological performance [27]. It is a well-known fact that, under EDU treatment, the sensitive plants showed significant responses to $\mathrm{O}_{3}$, while tolerant plants showed only limited responses [32,36]. The ozone sensitivity of different cultivar types such as for wheat [32,37] and rice [38] cultivars are widely known. We also found an interactive effect of both treatment and cultivar for all the studied enzymes, which again highlights the fact that EDU alteration is directly influenced by the $\mathrm{O}_{3}$ sensitivity of different cultivars [10,39].

The mechanism of EDU action differed in all the cultivars as $\mathrm{P}_{\mathrm{s}}$, chlorophyll, SOR, SOD and CAT were maximally affected in HD 2987, while it maximally enhanced biomass in PBW 502; furthermore, antioxidative enzymes were induced upto certain limits. Apart from these two cultivars, Kharchiya 65 was maximally influenced with higher carotenoids content under EDU treatment with the lowest induction of antioxidative enzymes. 
The ameliorative role of EDU was manifested on yield under ambient $\mathrm{O}_{3}$ conditions, which showed a comparatively higher yield with respect to control. EDU supplementation helped the wheat plants in translocating more photosynthates to their reproductive parts and, therefore, played a significant role to minimize yield losses. Similar to this, a study performed in China also showed an increase in the yield characteristics of wheat after EDU treatment [40]. Feng et al. (2018) also reported $>25 \%$ yield reduction in the sensitive cultivars and $<10 \%$ for the tolerant ones [10]. The three wheat cultivars differed in their resource allocation strategy. The higher gain of yield may simply be explained by better defense due to the efficient induction of the antioxidant system as observed in HD 2987 (with comparative lower increase in biomass), while the lower gain of yield may be related due to a trade-off between biomass accumulation and the translocation of photosynthates to reproductive parts as in PBW 502, resulting in greater biomass at the cost of grain weight due to EDU treatment. Also greater biomass in PBW 502 can be attributed to other physiological or biochemical events in the developmental stages of this cultivar. It has also been shown that the sensitive cultivar allocates more of its resources towards defense actions in response to $\mathrm{O}_{3}$-affected reduction in biomass [18]. Although Kharchiya 65 showed a positive response under EDU treatment, that was the lowest because the constitutive mechanisms in this cultivar were already much more efficient in tolerating $\mathrm{O}_{3}$ stress.

The overall results proved the usefulness of EDU as a tool to monitor cultivar-specific sensitivity to ambient $\mathrm{O}_{3}$. A recent study by Pandey et al. (2019) also confirmed the use of EDU as an efficient tool to reveal the adverse impacts of $\mathrm{O}_{3}$ eleven wheat cultivars and also helped to classify their relative sensitivity/tolerance to $\mathrm{O}_{3}$ [13]. This classification of cultivars will provide useful information for supporting the selection of the best-suited cultivars in areas with different $\mathrm{O}_{3}$ concentrations. The sensitivity in different cultivars was mostly due to the differential responses of different physiological and biochemical defense responses. EDU protects the plant by delaying the process of senescence, enhancing growth, biomass and economic yield, although the magnitude of these effects was cultivar specific. The present study confirms our earlier observation of the wheat cultivar sensitivity to $\mathrm{O}_{3}$. These results suggest EDU should be more frequently used as a tool for biomonitoring in such types of studies in the absence of sophisticated chamber experiments [30,31]. Our hypothesis was partly confirmed as EDU helped in mitigating the deleterious $\mathrm{O}_{3}$ effect through a different mechanism in the differentially sensitive cultivars, although conclusive evidence of how EDU protects plants still needs to be resolved. Unlike experiments using open top chambers (OTCs), EDU experiments can effectively provide estimations of the extent of damage to crop yields against $\mathrm{O}_{3}$ and the effects on other parameters without bearing complexities associated with the micro-environment as faced during enclosure techniques $[30,31]$ while providing similar results as also observed in OTC studies. Similar to our previous study [9], the present study also found total plant biomass to be important trait in identifying $\mathrm{O}_{3}$ sensitivity in different cultivars, which was also found to indirectly influence the overall yield response. This study helped in validating the cultivar response and $\mathrm{O}_{3}$ sensitivity using a cheap method with no set-up requirement.

\section{Materials and Methods}

\subsection{Experimental Site and Plant}

The experiment was executed during the wheat growth period, extending from mid-December 2015 to the end of March 2016, at the experimental field of the botanical garden in the campus of Banaras Hindu University, Varanasi, India, at an altitude of $76 \mathrm{~m}$ a.s.l. and located in the Eastern Gangetic plains of North India-with an overall soil texture that includes 45, 28 and 27\% sand, silt and clay, respectively, and has a $\mathrm{pH}$ ranging from 7.2-7.4. Based on the prior screening experiment, three wheat cultivars (T. aestivum cvs) with different levels of $\mathrm{O}_{3}$ sensitivity were selected, namely, HD 2987 (sensitive), PBW 502 (intermediately sensitive) and Kharchiya 65 (tolerant) [9]. HD 2987 had a plant height of 86-94 cm, a maturity period of 128-134 days and was drought tolerant. PBW 502 had a plant height of 80-94 cm, a maturity period of 128-139 days and was tolerant to heat and lodging, 
while Kharchiya 65 had a plant height of 111-130 cm, a maturity period of 132-142 days and was salinity/alkalinity tolerant. The average yield varied from 3.2, 4.6 and 4.2 tonnes/hectare for HD 2987, PBW 502 and Kharchiya 65, respectively.

\subsection{Raising of Plants and EDU Treatment}

The experimental plot (split-split plot design) was an open plot consisting of three blocks, namely, A, B and C (separated by $0.2 \mathrm{~m}$ from one another). Each block was then further separated into two sub-blocks (EDU- and non-EDU-treated). Each sub-block was further divided into three blocks or sub-subblocks $(1 \times 1$ sq. $m$ dimensions) represented by each of the three cultivars $(a, b, c)$ (Figure 5). The entire plot was prepared using Indian standards of agronomic practices. [41]. During the field preparation, urea, muriate of potash and superphosphate were added $\left(120,40\right.$ and $80 \mathrm{~kg} \mathrm{ha}^{-1}$, respectively) as the source of N, K and P, respectively. Seeds were manually sown in the first week of December inside each block and, after germination, a total of 36 plants were maintained in each plot. Dr. Lisa Emberson, of Stockholm Environment Institute, University of York, UK, provided EDU as a gift. A freshly prepared EDU solution (400 ppm; prepared using $400 \mathrm{mg}$ EDU in lukewarm distilled water with a final volume adjusted to $1 \mathrm{~L}$ ) was given as a soil drench to each plant (in EDU treatments) at an interval of every $10 \mathrm{~d}$ while the first dose was applied at 10 DAG. This prescribed concentration of EDU most effectively showed positive results on field crops [23] and was, therefore, used in our experiment. In EDU treatments, up to 40 DAG and $100 \mathrm{~mL}$ EDU solution were added with subsequent addition of $200 \mathrm{~mL}$ until there were $90 \mathrm{DAG}$, making up a total of nine applications to individual plants. Control plants (no EDU treatment) were provided with a similar amount of water for maintenance of equal water regime.

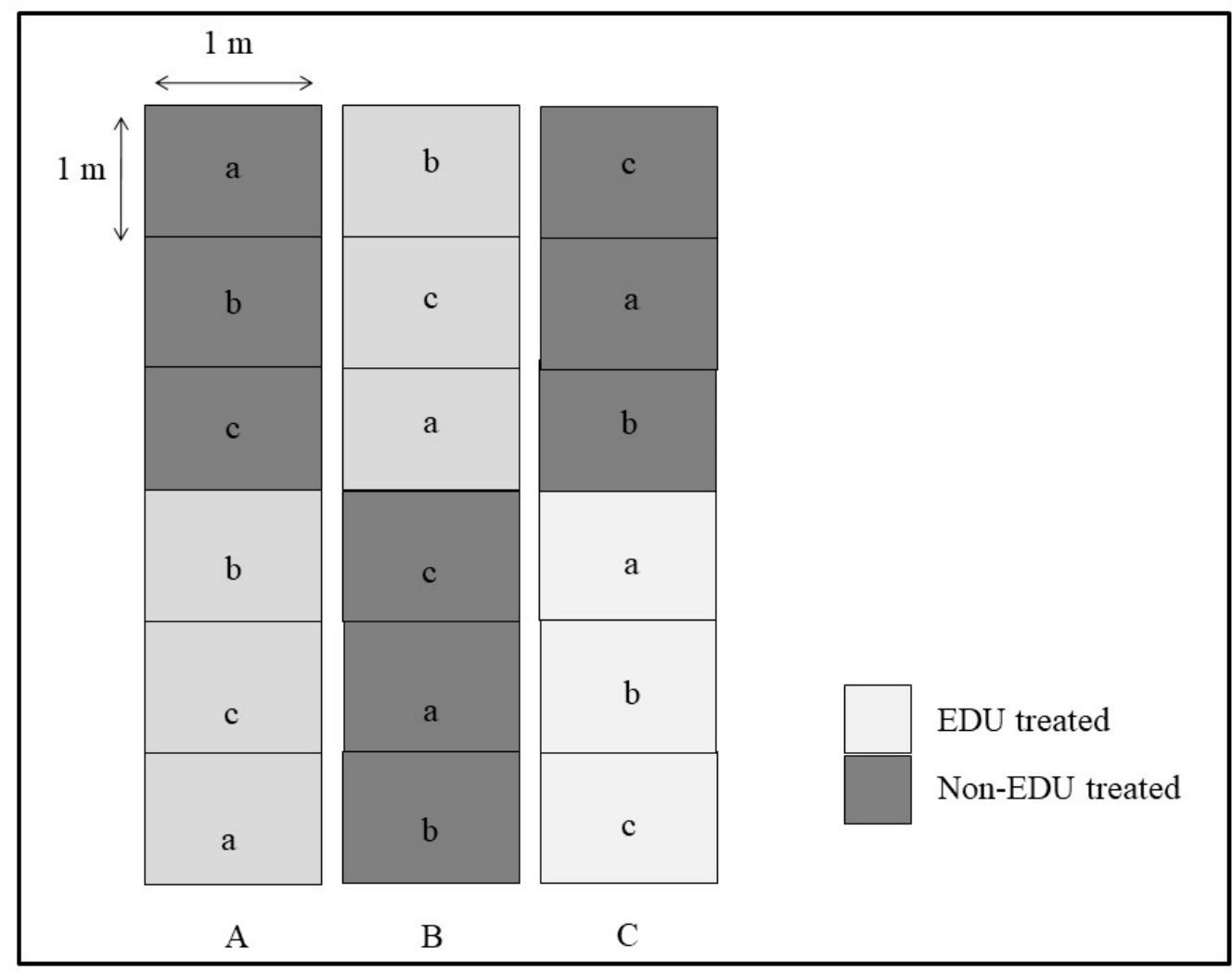

Figure 5. The layout of the whole plot, consisting of three main blocks (A, B and C) with twosub-plots (EDU-treated and non-EDU-treated) and a further threesub-subplots ( $a, b$ and c). Here, a, b and c are three different wheat cultivars (HD 2987, PBW 502 and Kharchiya 65). 


\subsection{Meteorological Data}

Meteorological data collected during the similar study period showed the average maximum temperature of $33.5^{\circ} \mathrm{C}$ in March and the average minimum temperature in January $\left(10.2^{\circ} \mathrm{C}\right)$. Seasonal average relative humidity during the study period was $55.7 \%$, while the average number of bright sunshine hours was $6.5 \mathrm{~h}$ with a maximum of $8.7 \mathrm{~h}$ in the month of March. All data were collected from the Indian Meteorological Division (IMD) located in the Banaras Hindu University campus.

\subsection{Ozone Monitoring}

The ambient $\mathrm{O}_{3}$ concentration at the experimental site was monitored using an automatic $\mathrm{O}_{3}$ analyzer (Horiba, APOA-370, Japan) on eight $\mathrm{h}$ day $^{-1}$ from 09:00 to 17:00 $\mathrm{h}$. Air samples $(0.72 \mathrm{~L} / \mathrm{min})$ were drawn in through a Teflon tube $(0.35 \mathrm{~cm}$ in diameter and $4 \mathrm{~cm}$ in height) above the plant's canopy. For the ambient $\mathrm{O}_{3}$ concentration, mean hourly values were calculated followed by the calculation of mean monthly $\mathrm{O}_{3}$ concentration. The exposure index for $\mathrm{O}_{3}$, i.e., AOT 40, was calculated by the formula given by Mauzerall and Wang (2001) [42].

$$
\mathrm{AOT} 40=\sum_{i=1}^{n}\left[\mathrm{Co}_{3}-40\right]
$$

where, $\mathrm{Co}_{3}$ denotes the mean $\mathrm{O}_{3}$ values per hour $\mathrm{ppb}, i$ is the index, and $n$ indicates the number of hours where $\mathrm{O}_{3}$ values were above $40 \mathrm{ppb}$.

\subsection{Growth Parameters and Total Biomass}

Plants with intact roots were uprooted at 60 DAG for assessing the growth parameters and total biomass. Five plants per cultivar were taken randomly from sub-subplots of each treatment and were thoroughly washed under tap water to remove all adhered soil particles. Further, the growth parameters such as the height of the plant, number of tillers plant ${ }^{-1}$, number of leaves and senesced leaves plant ${ }^{-1}$ were recorded. Plant parts such as the root, stem and leaves were first separated and then dried in an oven at $80^{\circ} \mathrm{C}$ until constant weights were achieved.

\subsection{Physiological Parameters}

Aportable photosynthetic system (LICOR/LI-6400 XT Biosciences, Inc., Lincoln, NE, USA) was utilized to assess $P_{s}$ and $g_{s}$ on fully expanded third leaves from the top at 60 DAG. These measurements were recorded on cloud-free days during 09:00 and 10:30 $\mathrm{h}$ and five plants cultivar ${ }^{-1}$ from three sub-subplots of each treatment were chosen randomly for measurement. Leaves were illuminated with a photosynthetic photon flux density (PPFD) of $1200 \mu \mathrm{mol} \mathrm{m}^{-2} \mathrm{~s}^{-1}$ using an internal light source of the leaf chamber. The leaf temperature, flow rate and $\mathrm{CO}_{2}$ concentration were $25.0{ }^{\circ} \mathrm{C}, 300 \mu \mathrm{mol} \mathrm{s}{ }^{-1}$ and $400 \mathrm{ppm}$, respectively. Chlorophyll, a fluorescence or photosynthetic efficiency (Fv/Fm), was measured for the different treatments using the Portable Plant Efficiency Analyzer (PEA, Hansatech Instument Ltd., UK) on the tagged leaves where gas exchanges were measured. Leaf clips were attached on the adaxial leaf surfaces for adaptation under dark condition $(30 \mathrm{~min}$ ) and then measurement was taken at $3000 \mu \mathrm{mol} \mathrm{m}^{-2} \mathrm{~s}^{-1}$ irradiance excitation.

\subsection{Biochemical Parameters}

For all biochemical parameters, fully expanded third leaves from the top $(n=3)$ were taken at 60 DAG from the respective sub-subplots of each treatment. Photosynthetic pigments were estimated by taking $0.1 \mathrm{~g}$ fresh leaf samples which were homogenized in $80 \%$ acetone and the absorbance was recorded at 480 and $510 \mathrm{~nm}$ for carotenoids content and at 645 and $663 \mathrm{~nm}$ for chlorophyll a and b. The formula by Maclachlan and Zalik (1963) was used for the calculation of chlorophyll content and the formula given by Duxbury and Yentsch (1956) was used for calculating carotenoids content [43,44]. SOR $\left(\mathrm{O}_{2}{ }^{-}\right)$was estimated following the rate of nitrite formation by reacting with hydroxylamine in 
the presence of $\mathrm{O}_{2}{ }^{-}$[45]. For this, $0.5 \mathrm{~g}$ leaf sample was homogenized in $3 \mathrm{~mL}$ of $65 \mathrm{mM}$ phosphate buffer (pH-7.8) and the final absorbance of the pale-yellow colored solution was measured at $530 \mathrm{~nm}$. Antioxidative enzymes (SOD, ascorbate peroxidase (APX), catalase (CAT) and POX) activities were assayed and calculated following the methodologies already provided by Singh et al. (2014) [46].

\subsection{Yield}

For estimation of the yield, the weight of the grains per plant was estimated after 135 DAG. Fully mature healthy grains were considered form three different plants of each cultivar from each sub-subplots $(\mathrm{n}=9)$.

\subsection{Statistical Analyses}

Before the statistical analysis data were checked for normal distribution by the KolmogorovSmirnov test and the homogeneity of variance was checked by Levene test, the non-normal data were $\log$ transformed to meet the assumptions of the analysis of variance (ANOVA).To test the main effect of EDU treatment, cultivars and their interaction on different studied parameters (dependent variable), a mixed-design analysis of variance or split-plot ANOVA were performed. To test the significant variability between EDU- and non-EDU-treated plants for each cultivar univariate, ANOVA was performed followed by Tukey's post hoc test to assess variations among the three different cultivars. For each of the analyses, each sub-subplot was taken as a statistical unit. To identify the association between different parameters tested, principal component analysis (PCA) was executed utilizing the correlation matrix and varimax rotation method. All the statistical tests were undertaken using SPSS software (SPSS Inc., version 23.0).

\section{Conclusions}

EDU application was found to be a useful tool in the ranking of cultivar-specific sensitivity in the present study. EDU helped wheat plants accumulate more biomass under ambient $\mathrm{O}_{3}$ conditions. The most sensitive cultivar, HD 2987, showed better performance under EDU treatment and ultimately led to a maximum increment in yield. EDU had no direct physiological effect but helped to mitigate the deleterious $\mathrm{O}_{3}$ effect primarily by scavenging $\mathrm{ROS}$ and enhancing the antioxidative defense system, thus delaying senescence and, thereby, reducing chlorophyll loss and enhancing the growth, biomass and yield of wheat cultivars. It was also found that the mechanisms of their relative sensitivity were not similar in different cultivars and SOD emerged as the major responsive biochemical parameter in providing protection against ambient $\mathrm{O}_{3}$. Thus, the short-term adaptive strategies may include the cultivation of wheat cultivars that are both $\mathrm{O}_{3}$ tolerant and high yielding, while the most $\mathrm{O}_{3}$-sensitive cultivars should be avoided.

Author Contributions: Performed the experiment, analyzed the data and prepared the manuscript, A.F. and A.A.S.; Manuscript correction and data presentation, A.M. and T.D.; Designed and supervised the experiment, provided necessary laboratory and technical facilities and structured the manuscript, S.B.A. and M.A.

Funding: This work was supported by the Science and Engineering Research Board (Department of Science and Technology), New Delhi, providing financial support to the work in the form of a major research project (SERB/PO/PS-62/2013).

Acknowledgments: The authors are grateful to the Head, Department of Botany, Department of Science and Technology (DST-FIST), UGC (University Grants Commission), Centre of Advanced Study (CAS), Interdisciplinary School of Life Sciences (ISLS), UGC-UPE (University with Potential for Excellence) Phase-II, BHU, DST-PURSE and Centre of International Climate Research (CICERO), Oslo, Norway for all the research facilities. We are grateful to Dr. G.P. Singh [Director, ICAR-IIWBR (Indian Institute of Wheat and Barley Research), Karnal] for providing the wheat seeds for this study.

Conflicts of Interest: The authors declare that they have no conflict of interest. 


\section{References}

1. Ainsworth, E.A. Understanding and improving global crop response to ozone pollution. Plant J. 2017, 90, 886-897. [CrossRef] [PubMed]

2. FAO (Food and Agricultural Organisation of the United Nations). How to Feed the World in 2050. 2009. Available online: http:/ / www.fao.org/wsfs/docs/expertpaper (accessed on 13 December 2018).

3. Monks, P.S.; Archibald, A.T.; Colette, A.; Cooper, O.; Coyle, M.; Derwent, R.; Fowler, D.; Granier, C.; Law, K.S.; Mills, G.E.; et al. Tropospheric ozone and its precursors from the urban to the global scale from air quality to short-lived climate forcer. Atmos. Chem. Phys. 2015, 15, 8889-8973. [CrossRef]

4. Van Dingenen, R.; Dentener, F.J.; Raes, F.; Krol, M.C.; Emberson, L.; Cofala, J. The global impact of ozone on agricultural crop yields under current and future air quality legislation. Atmos. Environ. 2009, 43, 604-618. [CrossRef]

5. Avnery, S.; Mauzerall, D.L.; Liu, J.; Horowitz, L.W. Global crop yield reductions due to surface ozone exposure: 2. Year 2030 potential crop production losses and economic damage under two scenarios of $\mathrm{O}_{3}$ pollution. Atmos. Environ. 2011, 45, 2297-2309. [CrossRef]

6. Tai, A.P.; Martin, M.V.; Heald, C.L. Threat to future global food security from climate change and ozone air pollution. Nat. Clim. Chang. 2014, 4, 817. [CrossRef]

7. Lal, S.; Venkataramani, S.; Naja, M.; Kuniyal, J.C.; Mandal, T.K.; Bhuyan, P.K.; Kumari, K.M.; Tripathi, S.N.; Sarkar, U.; Das, T.; et al. Loss of crop yields in India due to surface ozone: An estimation based on a network of observations. Environ. Sci. Pollut. Res. 2017, 24, 20972-20981. [CrossRef] [PubMed]

8. Carnahan, J.E.; Jenner, E.L.; Wat, E.K.W. Prevention of ozone injury to plants by a new protectant chemical. Phytopathology 1978, 68, 1229. [CrossRef]

9. Singh, A.A.; Fatima, A.; Mishra, A.K.; Chaudhary, N.; Mukherjee, A.; Agrawal, M.; Agrawal, S.B. Assessment of ozone toxicity among 14 Indian wheat cultivars under field conditions: Growth and productivity. Environ. Monit. Assess. 2018, 190, 190. [CrossRef] [PubMed]

10. Feng, Z.; Jiang, L.; Calatayud, V.; Dai, L.; Paoletti, E. Intraspecific variation in sensitivity of winter wheat (Triticum aestivum L.) to ambient ozone in northern China as assessed by ethylenediurea (EDU). Environ. Sci. Pollut. Res. 2018, 25, 29208-29218. [CrossRef]

11. Wahid, A.; Ahmad, S.S.; Zhao, Y.; Bell, J.N.B. Evaluation of ambient air pollution effects on three cultivars of sesame (Sesamum indicum L.) by using ethylenediurea. Pak. J. Bot. 2012, 44, 99-110.

12. Singh, S.; Agrawal, M.; Agrawal, S.B.; Emberson, L.; Bueker, P. Use of ethylenediurea for assessing the impact of ozone on mung bean plants at a rural site in a dry tropical region of India. Int. J. Environ. Waste Manag. 2010, 5, 125-135. [CrossRef]

13. Pandey, A.K.; Majumder, B.; Keski-Saari, S.; Kontunen-Soppela, S.; Pandey, V.; Oksanen, E. High Variation in Resource Allocation Strategies among 11 Indian Wheat (Triticum aestivum) Cultivars Growing in High Ozone Environment. Climate 2019, 7, 23. [CrossRef]

14. FAO (Food and Agricultural Organisation of the United States). World Food Situation: FAO Cereal Supply and Demand Brief. 2016. Available online: http://www.fao.org/worldfoodsituation (accessed on 3 December 2018).

15. Feng, Z.; Wang, L.; Pleijel, H.; Zhu, J.; Kobayashi, K. Differential effects of ozone on photosynthesis of winter wheat among cultivars depend on antioxidative enzymes rather than stomatal conductance. Sci. Total Environ. 2016, 572, 404-411. [CrossRef] [PubMed]

16. Yuan, X.; Calatayud, V.; Jiang, L.; Manning, W.J.; Hayes, F.; Tian, Y.; Feng, Z. Assessing the effects of ambient ozone in China on snap bean genotypes by using ethylenediurea (EDU). Environ. Pollut. 2015, 205, 199-208. [CrossRef]

17. Pandey, A.K.; Majumder, B.; Keski-Saari, S.; Kontunen-Soppela, S.; Mishra, A.; Sahu, N.; Pandey, V.; Oksanen, E. Searching for common responsive parameters for ozone tolerance in 18 rice cultivars in India: Results from ethylenediurea studies. Sci. Tot Environ. 2015, 532, 230-238. [CrossRef] [PubMed]

18. Gupta, S.K.; Sharma, M.; Majumder, B.; Maurya, V.K.; Lohani, M.; Deeba, F.; Pandey, V. Impact of Ethylene diurea (EDU) on growth, yield and proteome of two winter wheat varieties under high ambient ozone phytotoxicity. Chemosphere 2018, 196, 161-173. [CrossRef] [PubMed] 
19. Tiwari, S.; Agrawal, M.; Manning, W.J. Assessing the impact of ambient ozone on growth and productivity of two cultivars of wheat in India using three rates of application of ethylenediurea (EDU). Environ. Pollut. 2005, 138, 153-160. [CrossRef] [PubMed]

20. Agrawal, S.B.; Singh, A.; Rathore, D. Role of ethylene diurea (EDU) in assessing impact of ozone on Vigna radiata L. plants in a suburban area of Allahabad (India). Chemosphere 2005, 61, 218-228. [CrossRef] [PubMed]

21. Pandey, A.K.; Majumder, B.; Keski-Saari, S.; Kontunen-Soppela, S.; Pandey, V.; Oksanen, E. Differences in responses of two mustard cultivars to ethylenediurea (EDU) at high ambient ozone concentrations in India. Agric. Ecosyst. Environ. 2014, 196, 158-166. [CrossRef]

22. Rai, R.; Agrawal, M.; Choudhary, K.K.; Agrawal, S.B.; Emberson, L.; Büker, P. Application of ethylene diurea (EDU) in assessing the response of a tropical soybean cultivar to ambient $\mathrm{O}_{3}$ : Nitrogen metabolism, antioxidants, reproductive development and yield. Ecotox. Environ. Saf. 2015, 112, 29-38. [CrossRef]

23. Feng, Z.; Wang, S.; Szantoi, Z.; Chen, S.; Wang, X. Protection of plants from ambient ozone by applications of ethylenediurea (EDU): A meta-analytic review. Environ. Pollut. 2010, 158, 3236-3242. [CrossRef] [PubMed]

24. Agathokleous, E.; Saitanis, C.J.; Stamatelopoulos, D.; Mouzaki-Paxinou, A.C.; Paoletti, E.; Manning, W.J. Olive oil for dressing plant leaves so as to avoid $\mathrm{O}_{3}$ injury. Water Air Soil Pollut. 2016, 227, 282. [CrossRef]

25. Agathokleous, E.; Mouzaki-Paxinou, A.C.; Saitanis, C.J.; Paoletti, E.; Manning, W.J. The first toxicological study of the antiozonant and research tool ethylene diurea (EDU) using a Lemna minor L. bioassay: Hints to its mode of action. Environ. Pollut. 2016, 213, 996-1006. [CrossRef]

26. Zheng, Y.; Shimizu, H.; Barnes, J.D. Limitations to $\mathrm{CO}_{2}$ assimilation in ozone-exposed leaves of Plantago major. New Phytol. 2002, 155, 67-78. [CrossRef]

27. Tiwari, S.; Agrawal, M. Effectiveness of different EDU concentrations in ameliorating ozone stress in carrot plants. Ecotox. Environ. Saf. 2010, 73, 1018-1027. [CrossRef]

28. Singh, A.A.; Chaurasia, M.; Gupta, V.; Agrawal, M.; Agrawal, S.B. Responses of Zea mays L. cultivars 'Buland' and 'Prakash' to an antiozonant ethylene diurea grown under ambient and elevated levels of ozone. Acta Physiol. Plant. 2018, 40, 1-15. [CrossRef]

29. Paoletti, E.; Contran, N.; Manning, W.J.; Castagna, A.; Ranieri, A.; Tagliaferro, F. Protection of ash (Fraxinus excelsior) trees from ozone injury by ethylenediurea (EDU): Roles of biochemical changes and decreased stomatal conductance in enhancement of growth. Environ. Pollut. 2008, 155, 464-472. [CrossRef] [PubMed]

30. Tiwari, S. Ethylenediurea as a potential tool in evaluating ozone phytotoxicity: A review study on physiological, biochemical and morphological responses of plants. Environ. Sci. Pollut. Res. 2017, 24, 14019-14039. [CrossRef]

31. Paoletti, E.; Contran, N.; Manning, W.J.; Ferrara, A.M. Use of the antiozonant ethylenediurea (EDU) in Italy: Verification of the effects of ambient ozone on crop plants and trees and investigation of EDU's mode of action. Environ. Pollut. 2009, 157, 1453-1460. [CrossRef]

32. Singh, S.; Agrawal, S.B.; Agrawal, M. Differential protection of ethylenediurea (EDU) against ambient ozone for five cultivars of tropical wheat. Environ. Pollut. 2009, 157, 2359-2367. [CrossRef] [PubMed]

33. Singh, S.; Singh, P.; Agrawal, S.B.; Agrawal, M. Use of Ethylenediurea (EDU) in identifying indicator cultivars of Indian clover against ambient ozone. Ecotox. Environ. Saf. 2018, 147, 1046-1055. [CrossRef]

34. Paoletti, E.; De Marco, A.; Beddows, D.C.; Harrison, R.M.; Manning, W.J. Ozone levels in European and USA cities are increasing more than at rural sites, while peak values are decreasing. Environ. Pollut. 2014, 192, 295-299. [CrossRef]

35. Manning, W.J.; Paoletti, E.; Sandermann, H., Jr.; Ernst, D. Ethylenediurea (EDU): A research tool for assessment and verification of the effects of ground level ozone on plants under natural conditions. Environ. Pollut. 2011, 159, 3283-3293. [CrossRef] [PubMed]

36. Szantoi, Z.; Chappelka, A.H.; Muntifering, R.B.; Somers, G.L. Use of ethylenediurea (EDU) to ameliorate ozone effects on purple coneflower (Echinacea purpurea). Environ. Pollut. 2007, 150, 200-208. [CrossRef] [PubMed]

37. Biswas, D.K.; Xu, H.; Li, Y.G.; Liu, M.Z.; Chen, Y.H.; Sun, J.Z.; Jiang, G.M. Assessing the genetic relatedness of higher ozone sensitivity of modern wheat to its wild and cultivated progenitors/relatives. J. Exp. Bot. 2008, 59, 951-963. [CrossRef]

38. Akhtar, N.; Yamaguchi, M.; Inada, H.; Hoshino, D.; Kondo, T.; Fukami, M.; Funada, R.; Izuta, T. Effects of ozone on growth, yield and leaf gas exchange rates of four Bangladeshi cultivars of rice (Oryza sativa L.). Environ. Pollut. 2010, 158, 2970-2976. [CrossRef] [PubMed] 
39. Agathokleous, E. Perspectives for elucidating the ethylenediurea (EDU) mode of action for protection against $\mathrm{O}_{3}$ phytotoxicity. Ecotox. Environ. Saf. 2017, 142, 530-537. [CrossRef] [PubMed]

40. Wang, X.; Zheng, Q.; Yao, F.; Chen, Z.; Feng, Z.; Manning, W.J. Assessing the impact of ambient ozone on growth and yield of a rice (Oryza sativa L.) and a wheat (Triticum aestivum L.) cultivar grown in the Yangtze Delta, China, using three rates of application of ethylenediurea (EDU). Environ. Pollut. 2007, 148, 390-395. [CrossRef]

41. Annual Report 2012-2013 (2013). Directorate of Wheat Research, Karnal, India. Available online: https: / / farmer.gov.in/imagedefault/pestanddiseasescrops/wheatannualreport2013.pdf (accessed on 15 July 2017).

42. Mauzerall, D.L.; Wang, X. Protecting agricultural crops from the effects of tropospheric ozone exposure: Reconciling science and standard setting in United States, Europe and Asia. Annu. Rev. Energy Environ. 2001, 26, 237-287. [CrossRef]

43. Machlachan, S.; Zalik, S. Plastid structure, chlorophyll concentration and free amino acid composition of a chlorophyll mutant of barley. Can. J. Bot. 1963, 41, 1053-1062. [CrossRef]

44. Duxbury, A.C.; Yentsch, C.S. Plankton pigment monographs. J. Mar. Res. 1956, 15, 91-101.

45. Elstner, E.F.; Heuper, A. Inhibition of nitrite formation from hydroxylammonium chloride: A simple assay for superoxide dismutase. Ann. Biochem. 1976, 70, 616-620. [CrossRef]

46. Singh, A.A.; Agrawal, S.B.; Shahi, J.P.; Agrawal, M. Investigating the response of tropical maize (Zea mays L.) cultivars against elevated levels of $\mathrm{O}_{3}$ at two developmental stages. Ecotoxicology 2014, 23, 1447-1463. [CrossRef] [PubMed]

(C) 2019 by the authors. Licensee MDPI, Basel, Switzerland. This article is an open access article distributed under the terms and conditions of the Creative Commons Attribution (CC BY) license (http:/ / creativecommons.org/licenses/by/4.0/). 